KEYWORDS

International finance

Financial liberalization

Capital movements

Economic development

Development finance

Development assistance

Financial instruments

External debt
Jorge García-Arias

Associate Professor of Economics Economics Department University of León,

Spain

- jrgara@unileon.es

\section{International finance and development: opportunity or threat?}

\author{
Jorge Garcia-Arias
}

$\mathrm{T}$

he volume of assets traded on international financial markets has reached gigantic proportions. The question must arise, then, as to whether international finance might play a decisive role in the provision of stable resources in the quantities needed to fund development. This article analyses the function that international finance might perform and that it actually has performed, focusing specifically on the analysis of private capital flows, official development assistance and external borrowing. It concludes that there need to be far-reaching structural reforms in the workings of the international financial system and in development financing instruments and mechanisms if these are to be placed at the service of long-term development goals. 


\section{I}

\section{Introduction}

Even the most unsophisticated analyses of international financial statistics reveal a huge disparity between the amount of assets circulating in international financial markets and the volume of such assets destined for the financing of development activities. For example, the latest official data show that assets worth US\$ 3.2 trillion are traded on the currency market each day, giving a range of between US\$ 832 trillion and US\$ 1,000 trillion during 2007 in that market alone (BIS, 2007). Meanwhile, the leading providers of official development assistance donated a little over US\$ 100 billion in such assistance between them in 2007 (OECD, 2008), whereas the most rigorous studies of the subject estimate that at least a further US\$ 50 billion would be needed each year to achieve the main long-term development objectives (Atkinson, 2005).

The astonishing scale of transactions in international financial markets is the outcome of a long process of international financial liberalization which has been intensifying the interconnections between national banking, monetary and financial systems and leading to the de facto emergence of a global financial space to which they are being subordinated. This process, in turn, is a consequence of a radical overhaul of the system for regulating financial operations and overseeing capital movements that began with the opening of the Euromarket in the late 1950s, gained irresistible momentum in the 1970s and intensified in the following two decades.

This phenomenon of financial globalization is the outcome of a complex process that can be characterized by a number of elements, including an increased technical ability to develop advanced financial relationships, the integration of national markets and local agents into a more global market, a blurring of the traditional distinctions between financial institutions of various kinds and the businesses and markets they serve, and the emergence of banking and financial conglomerates of global proportions. ${ }^{1}$

\footnotetext{
${ }^{1}$ For a detailed analysis see, for example, Palazuelos (1998).
}

At the same time, financial globalization has consolidated two kinds of asymmetries of immense importance: first, a situation in which a clearly hegemonic currency of reference, the dollar, underpins all financial and trading relationships, ${ }^{2}$ and second, an apparently democratized global financial market with innumerable small agents interacting freely within it, although a more detailed analysis reveals a clearly oligopolistic market in which a very small number of agents control the bulk of the resources channelled through it and there is clear evidence of herd behaviour among them (García-Arias, 2006).

This process of financial internationalization and liberalization, which had its theoretical roots in the first fundamental theorem of welfare economics (FTWE) and the efficient-market hypothesis (EMH), ${ }^{3}$ was meant to produce a win-win situation for all international actors. In general, capital would flow from highly developed countries (where it was in surplus and thus lower-yielding) to emerging countries (which were capital-deficient, so that returns on this factor were higher); this would speed up growth in the recipient countries and both the providers and recipients would benefit, as each would have greater opportunities of financial diversification. This general framework of potential benefits was supplemented by some more specific

\footnotetext{
2 The hegemonic role of the United States in this context of financial globalization is not manifested solely in the central role played by its currency. It also translates, for example, into the ability to implement economic policies that other economies would be unable to sustain, such as running twin deficits (current account deficit and fiscal deficit) and attracting external resources (partly to finance these twin deficits) on a scale that affects the availability of resources for other economies and thus the financing of development.

${ }^{3}$ In general, the fundamental theorem of welfare economics is concerned with efficiency in the real economy and the efficientmarket hypothesis links financial markets to macroeconomic fundamentals. In combination, they reflect a situation in which economic efficiency depends on liberalized factor, financial and goods and services markets and the smallest possible public sector. Financial liberalization (like other kinds) must necessarily be beneficial insofar as it would remove distortions affecting the free play of market forces, such distortions being, it is argued, inherently inefficient. See García-Arias (2002b) for a theoretical analysis.
} 
ones, such as increased competitiveness and efficiency in the system, international diversification of investment portfolios, higher expected returns, lower risk and much else.

This idyllic, mythological view of the operation of liberalized capital markets was suspended, to say the least, following a proliferation of studies calling it into question and empirically identifying problems representing serious cause for concern. The main problems include the unequal growth in opportunities for lenders and borrowers, the shifting of net resources to more developed countries, the enormous volatility of capital flows to countries with lower rates of development, the increased fragility of the international financial system owing to the intensification of currency, banking and financial crises and the increase in excessive borrowing from abroad. ${ }^{4}$ All this has been compounded by problems relating to both the origins (illegal activities, money-laundering) and the destinations (financing of illegal activities, tax havens) of this gigantic volume of capital.

In short, international finance could undoubtedly make a huge contribution to the growth and development of all the world's economies and to the well-being of humankind. There are difficulties, however, arising from the origin of the capital, its type, the way it circulates and its destination.

Thus, the many challenges thrown up by the financial internationalization and liberalization process have generated a major debate about the need to rethink this process and, above all, to modify the international financial architecture. ${ }^{5}$

From the development point of view, however, the main problem is that this process has not led to adequate capital flows being channelled to developing economies, let alone the least developed. There is a need, then, to analyse the relationship, not always an idyllic one, between these two phenomena: international finance and development.

\section{II}

\section{International finance and development}

\section{The situation at the turn of the century}

Until the early twenty-first century, international capital flows to developing countries had a number of distinctive characteristics (Ocampo, 1999a). First, institutional and private capital flows followed divergent trends: whereas the former were tending to diminish, the latter had been growing over the medium term.

Second, the different types of private capital flows differed enormously in terms of stability: whereas foreign direct investment (FDI) held up well during crises, private-sector financial flows showed marked volatility and contagion effects. In contrast to the dynamism of private capital flows, meanwhile, official development financing (and especially its main component, bilateral assistance funds) showed signs of aid fatigue, declining in real terms over the decade.

\footnotetext{
${ }^{4}$ It is beyond the scope of this essay to analyse these matters in detail. See Agüera Sirgo and García-Arias (2000) for a more in-depth analysis of the promises and realities of this process of financial liberalization and internationalization.
}

Third, private capital flows went mainly to middle-income countries, a trend only partly offset by the redistributive effects of public-sector financial flows at the world level.

Lastly, the volatility of private-sector financial flows, and the extent to which they were concentrated in middle-income countries, ended up by generating exceptional financing needs that were unprecedented in scale. This exceptional financing went to just a

\footnotetext{
${ }^{5}$ While the idea of reforming the international financial architecture is variously understood by different authors, we normally include under this heading (the list is not necessarily exhaustive) aspects relating to: (i) improved transparency and accounting standards, (ii) increased self-regulation and/or external supervision, (iii) modification of capital account management mechanisms, (iv) alterations in the choice of exchange-rate regimes, (v) the design of national economic policies and those proposed by international economic organizations, (vi) the provision of international liquidity and (vii) lender of last resort mechanisms and international bankruptcies and defaults. The issue has been intensively studied in the economic literature, with exponential growth in the last decade. The present paper obviously does not set out to expound the different contributions and approaches to the issue, but the interested reader may consult Caballero (2003), Eatwell (2002), Eichengreen (1999), Griffith-Jones, Gottschalk and Cailloux (2003), Kenen (2001) and Ocampo (1999b), among many others.
} 
few emerging economies. Consequently, financing from the International Monetary Fund (IMF), including that provided under the Enhanced Structural Adjustment Facility, displayed a marked countercyclical tendency in relation to private capital flows and went only to a small number of countries, which were required to comply with economic policy requirements (structural adjustment) too well known to need recounting here.

In this state of affairs, while the volatility and contagion characterizing private capital flows were undoubtedly problematic, so were the exclusion of the poorest countries from these flows and the reduction of the bilateral assistance on which they largely depended. Reform of the international financial structure therefore had to provide solutions to all these problems. Furthermore, the excessive borrowings of many developing countries, especially the poorest, continued to place severe constraints on their development potential.

In this context, the heads of State and government meeting at the International Conference on Financing for Development in Monterrey, Mexico under the auspices of the United Nations adopted a resolution to deal with problems of this nature: the Monterrey Consensus (United Nations, 2002).

\section{The Monterrey Consensus}

The Monterrey Consensus is built on the idea that international development cooperation needs to be treated as a task for developed countries and underdeveloped and/or developing countries (UDCs) alike.

More specifically, in this alliance each UDC accepts that it has primary responsibility for its own development and that it must (i) improve its internal governance, (ii) fight corruption, (iii) implement policies and investments conducive to growth and employment and (iv) maximize the domestic resources available to finance additional development strategies. For their part, the developed countries agree that those UDCs which adopt transparent, credible and well-designed development strategies should receive maximum support in the form of (i) greater development assistance, (ii) a more development-oriented international trade system, (iii) debt relief or forgiveness measures and (iv) an increase in private-sector development financing. Lastly, the international institutions standing behind the Consensus agree (i) to act more consistently, (ii) to coordinate and cooperate on the planning of their activities and the implementation of international development policies and (iii) to modify the structure and functioning of the international financial system to help achieve these goals.

To this end, the Monterrey Consensus distinguished six main aspects relating to development: (i) the mobilization of local financial resources in the UDCs themselves, (ii) the use of international trade as a development tool, (iii) flows of international private capital into UDCs, (iv) official development assistance, (v) external borrowing and (vi) the international financial system and its relationship to development financing.

Although the first two of these are certainly crucial components of a holistic approach to development financing, strictly speaking they are outside the sphere of international finance on which the present essay focuses. Again, as already suggested, it is clear that the general architecture of the international financial system needs to be modified for the purpose, among others, of turning financial liberalization into a dynamic force for development. In any event, the rest of this paper will concentrate on issues related to private capital flows, official development assistance (ODA) and external borrowing.

\section{III}

\section{International private capital flows}

In theory, private capital flows can play a very important role in the development of the recipient countries. As we have noted, however, the empirical evidence indicates that in recent decades these flows have not only been limited, volatile and highly reversible (being subject to herd behaviour and contagion effects), but have tended not to go to the poorest countries. 
Although instability, volatility and herd behaviour are inherent features of financial markets, both national and international, not all types of capital exhibit them in equal measure. Specifically, FDI is far more stable than other forms of capital (such as portfolio investment and bank lending).

Again, the international markets do not bear the whole responsibility for this situation. The financial systems of recipient countries also differ from those of more developed countries in ways that increase their vulnerability. These differences are as follows:

- the inability of many UDCs to issue debt obligations denominated in their own currencies, particularly long-term ones (the "original sin", according to Eichengreen, Hausmann and Panizza, 2003); this lies behind a whole range of weaknesses in national financial systems, as it ties them, essentially, to the dollar.

- differences in the development level of their financial systems and capital markets, resulting in limited availability of long-term financial instruments in these markets.

- the small size of these countries' domestic financial markets when compared to huge international financial markets.

The recent history of international capital movements includes three waves of private capital into UDCs. The first two occurred in the 1970s and 1990s.

- In the 1970s wave, rapid growth in bank lending to developing countries (as the enormous external surpluses of oil-producing countries were recycled and national and international financial markets were deregulated) was cut short by the debt crisis in Latin America (and other economic regions).

- The 1990s wave, dominated by FDI and portfolio investment flows, particularly into the countries of South-East Asia, was halted by the currency and financial crises suffered by those countries at the end of the decade, ${ }^{6}$ which then spread to Russia and Latin America.

The third wave began in 2003 and has continued until the present, as a result of improved economic conditions in the UDCs, strong global economic

\footnotetext{
${ }^{6}$ See García-Arias (2002a) for a detailed analysis of the Asian crises.
}

growth and a consistent policy of low interest rates in the developed countries.

This third cycle of renewed capital flows to UDCs is different, however, from the two earlier ones (Ocampo, Kregel and Griffith-Jones, 2007). Specifically, in 1997-2005 there was a net transfer of resources from UDCs to developed countries, essentially owing to the huge quantity of reserves being built up by developing countries (especially in South-East Asia) as insurance against future financial crises (like the one which had come to pass as this paper was being revised). Furthermore, capital flows became increasingly concentrated on UDCs in East and South-East Asia, and most particularly China, at the expense of Latin America.

Against this general background of renewed private capital flows into UDCs, the main concern of the latter is not just to know whether they will be sufficient to finance their development, but also to know whether they will be reasonably stable or, as has consistently been the case, highly volatile and reversible.

The first thing to be grasped here is that, as mentioned earlier, not all private capital flows (i.e., FDI, portfolio investment and bank lending) exhibit the same volatility.

FDI has three main components: investment in capital goods, local profits reinvested locally and intra-firm lending. In the latest cycle, FDI, and especially that destined for capital goods, has become the main source of external financing and has proved throughout history to be far more stable than other international flows. It also has other advantages, not least that it increases the productivity of recipient countries because it is accompanied by the transfer of technology and know-how and facilitates access to international markets for goods and finance.

Nonetheless, FDI does have some drawbacks. For example, its ties to the local economic structure tend to be very limited, it exacerbates trade deficits and it restricts competition and venture capital investment in the destination countries.

While there is intensive debate about the actual scale of the benefits from FDI and the time lag with which destination countries receive them, the economic literature is generally at one in agreeing that the net balance is positive, but with huge differences between and within countries.

In this latest cycle the benefits have clearly increased, which is encouraging, particularly because capital goods investment is accounting for about two 
thirds of total FDI (World Bank, 2004). Furthermore, some changes in the composition and destination of investment have been detected. The most striking is its rapid growth in the service sector, chiefly owing to the expansion of transnational enterprises in this segment in UDCs, often because of privatization. Although the anticompetitive behaviour characteristic of transnational enterprises usually has adverse consequences when local competition rules are lax, FDI in the tertiary sector has had different effects in the various economic areas to which it has gone. For example, the push of FDI into the service sector in Latin America appears to have had a crowding-out effect on local companies (Agosin and Mayer, 2000). Much the same has happened in the Latin American banking sector, although this orientation of FDI towards financial sectors seems to have generated more positive effects in South-East Asia (Asian Development Bank, 2004) and in eastern European countries (Weller, 2001). Another important aspect of FDI is the growth in South-South flows, which particularly benefit lower-income and less developed UDCs. Nonetheless, an overview of FDI reveals a problem: $75 \%$ of it goes to just 10 countries.

In view of all this, UDCs could apply a range of measures to increase the contribution made by FDI to their development, including: devising policies to strengthen ties between foreign and local firms; favouring exports with a high level of value added and the transfer of know-how, skills and technology; giving foreign firms incentives to invest in training; and creating a favourable domestic economic climate by means of infrastructure and training investments, transparent codes of conduct and regulatory stability.

Portfolio investment, meanwhile, tends to be procyclical and highly reversible and volatile. For years (in the two earlier waves) it was the main source of international private capital inflows into UDCs, peaking in 1996. From then on it fell off sharply as a result of the Asian currency and financial crises and the contagion from these, before recovering in recent years. Although its effects can be devastating in the event of a rapid reversal, it is still the main source of debt financing in UDCs, especially in Latin America.

Where bank lending is concerned, this can contribute to some extent to development, especially if it is linked to international trade. It is supplied by banks, financial and non-financial institutions, official export agencies, regional development banks, private insurers and specialist firms.

Its share increased strongly until the 1997 crisis; indeed, it bore much of the responsibility for that, basically by driving a boom-bust cycle (García-Arias, 2002a) and intensifying the herd behaviour of agents (García-Arias, 2006). Its role, particularly in the case of commercial lending, is of particular importance for low-income countries that have difficulty accessing other types of financing in international markets. This being the case, it would be advisable to encourage official export agencies and regional development banks such as the Inter-American Development Bank (IDB) and the Asian Development Bank to play a countercyclical role by guaranteeing and underwriting lending of this type.

\section{IV}

\section{Official development assistance}

\section{The traditional sources of official development assistance}

Official development assistance (ODA) still plays an essential role in supplementing the resources of UDCs, particularly in the case of very poor economies that find it especially hard to attract private capital. After peaking at $0.5 \%$ of the gross domestic product (GDP) of the most developed countries in the 1960s, however, this assistance fell to a historic low of $0.22 \%$ of GDP in the run-up to the agreements of the
United Nations Millennium Summit. The Monterrey Consensus restates the traditional goal of raising the level of assistance to at least $0.7 \%$ of donor country GDP (of which at least $0.15 \%-0.2 \%$ should go to heavily indebted poor countries (HIPCs).

In 2007, ODA from the main donors, i.e., the 22 member countries of the Development Assistance Committee (DAC), exceeded US\$ 103 billion, although this was $8.4 \%$ less than in 2006 . This assistance represented $0.28 \%$ of the combined GDP of the countries on the Committee (OECD, 2008). 
The fall in ODA after 2005 is due, paradoxically, to the type of assistance items that gave rise to the large increase that year. Thus, external debt forgiveness operations accounted for some US\$ 23 billion at a time when the total increase was somewhat over US\$ 26 billion. Discounting debt forgiveness operations in 2005 , ODA would have risen by only about $9 \%$ on the previous year in current dollars. Given the exceptional character of these assistance packages centred on debt forgiveness (and, to a much lesser degree, on emergency assistance after the devastating 2004 tsunami along the coasts of East and South-East Asia), this rate of increase was never likely to be sustained.

In valuing the amount of official development assistance, it needs to be borne in mind that, according to the data available, some US\$ 50 billion dollars a year of extra ODA is needed to achieve the most urgent development goals (United Nations, 2001). For example, ensuring universal primary schooling would require an extra US\$ 10 billion or so a year, halving extreme poverty some US\$ 20 billion more a year and reducing maternal and infant mortality US\$ 12 billion a year (HM Treasury, 2003). This leads to the conclusion that ODA levels have generally been inadequate.

Furthermore, while its total value began growing in the late 1990s, official development assistance presents some major problems:

(i) Its composition. Changes in the composition of ODA have made this type of assistance less likely to be effective in attaining sound development objectives. The reason is that the three components which have grown most in recent years are debt relief, emergency aid and technical cooperation. Although these all fulfil important functions, emergency aid is not designed to achieve long-term development goals and the real financial impact of technical cooperation is small, even though it may provide major development benefits. Where the attainment of development goals is concerned, therefore, ODA has been declining as a source of financing for recipient countries. This situation is particularly plain in the case of heavily indebted poor countries, since if emergency aid and debt relief are discounted, official development assistance has fallen by almost $50 \%$ since the start of the Millennium Development Goals programme (Ocampo, Kregel and Griffith-Jones, 2007). (ii) Its volatility. Investment and assistance flows need to be reasonably stable over time if longterm development goals are to be effectively attained. However, ODA flows have evinced a clear cyclical tendency associated with business cycles in the donor countries, their ideological, political or cultural affinity with recipient countries and changes in their development policies. This situation is made particularly serious by the fact that ODA in turn has a procyclical effect (Pallage and Robe, 2001; Bulir and Hamann, 2003): falling assistance levels lead to severe fiscal adjustments in the recipient countries (public spending cuts and revenue-raising measures), compounding the effects of the cut in assistance funding.

(iii) The conditions attached to it. Not only do donor countries impose specific conditions on recipients, but these are usually accompanied by a requirement for these countries to be members of the International Monetary Fund (IMF) and comply to a reasonable extent with its structural adjustment programmes. Failure to comply with IMF requirements produces a double blow: both IMF assistance and ODA funds from donor countries are forfeited.

(iv) Its geographical concentration. ODA is largely confined to a few recipient countries, which are those that have implemented structural reforms with the blessing of the international financial organizations and are seen by donors as efficient administrators of aid.

Again, it needs to be understood that there is no conclusive empirical evidence showing ODA to be effective at reducing poverty and stimulating growth and development. Numerous studies have found that this type of assistance works well only when it goes to countries that apply "sound policies", by which are meant those of the Washington Consensus (World Bank, 1998; Burnside and Dollar, 2000; Collier and Dollar, 2001). Other papers, conversely, put the findings of these studies down to problems with the econometric specification of the models (Hansen and Tarp, 2000; Beynon, 2003), and even find evidence that assistance enhances growth irrespective of the "political environment" (Morrissey, 2001). Some indeed conclude that it is not "sound policies" but other variables such as economic vulnerability, the existence of external shocks (Collier and Dehn, 2001), the presence of conflicts (Collier and Hoeffler, 2002) or even geographical factors (Dalgaard 
and Hansen, 2001) that significantly influence the effectiveness of such assistance.

Nonetheless, the issues of good governance, institutional change and the implementation of orthodox policies continue to dominate the debate.

In any event, donor countries are increasingly concerned about issues relating to the effectiveness of their assistance. In 2003, the High-Level Forum on Harmonization was held in Rome, followed by the High-Level Forum on Aid Effectiveness in Paris, with a view to drawing up a plan of action to harmonize donors' assistance policies and practices and procedures, both among themselves and with recipient countries.

Another interesting element of ODA is what has been called South-South cooperation, i.e., the fact that some UDCs donate development assistance to other UDCs. While the leading donor has traditionally been Saudi Arabia, followed by the United Arab Emirates and Kuwait, other nations such as China and the Republic of Korea have begun to participate and their weight is growing. These countries basically concentrate on technical cooperation or consultation and coordination forums, usually in specific economic or sectoral areas (one example is the IBSA Dialogue Forum, involving India, Brazil and South Africa).

\section{Innovative development financing instruments}

In recent years, owing mainly to the political difficulty of attaining the $0.7 \%$ goal for ODA as a share of donor country GDP, a number of non-traditional development financing proposals have appeared. They are very diverse, but in all cases the aim is to rapidly increase the volume of financial resources going to the development of poor countries with a view to maximizing the likelihood of the Millennium Development Goals being met by 2015 .

In its S-24/2 resolution of 1 July 2000, the United Nations General Assembly itself called for a rigorous analysis of advantages, disadvantages and other implications of a heterogeneous assortment of "new and innovative sources of funding, both public and private". The European Commission has also promoted study and debate in relation to these new development financing sources (Commission of the European Communities, 2005). ${ }^{7}$

\footnotetext{
${ }^{7}$ Some steps have been taken in this direction, since the United Nations has financed and published a study of the subject
}

This assortment of innovative development financing tools contains very heterogeneous proposals, but some of the main ones are: (i) platforms for issuing new financial instruments that can be used to advance development funding, such as the proposed International Finance Facility (IFF) or the issuing of new special drawing rights at the IMF, (ii) donations to public-private alliances and global funds, (iii) measures to give migrants' remittances a greater impact on development, (iv) global taxes (on certain financial transactions, the arms trade, emissions of polluting gases or air tickets) and (v) a world lottery.

The International Finance Facility is a development financing mechanism proposed by the United Kingdom (HM Treasury, 2003) that would allow aid disbursements to be prefinanced under a borrowing plan guaranteed by the participating States with a view to doubling current assistance flows so that the Millennium Goals can be met. This instrument would provide a new source of stable, predictable financing and would work as follows: first it would accept irrevocable formal multi-year commitments of future contributions from donor countries, which would be its shareholders; then it would issue bonds on the financial markets, repayment of which would be guaranteed by the donors' commitments. Being fully backed, these bonds would enjoy the highest credit rating, meaning that funding could be raised at interest rates lower than those the UDCs would have to pay if they borrowed themselves; lastly, the revenue generated by the bond issue would be distributed to developing countries in the form of donations, never loans. Furthermore, the funds would be "earmarked" for specific countries, programmes or projects determined by the donor countries, which could also set conditions for disbursement of the aid.

Special drawing rights (SDRs) are international reserve assets issued by the IMF to supplement the official reserves of member countries. They are allocated in proportion to each member's quota in the Fund and also act as an international unit of account, and their value is based on a basket of key international currencies. SDRs represent a potential claim on the freely usable currencies of IMF members. Holders of SDRs can obtain these currencies in exchange for their SDRs in two

by well-regarded world specialists in development financing (Atkinson, 2005). 
ways: first, through the arrangement of voluntary exchanges between members; and second, by the IMF designating members with strong external positions to purchase SDRs from members with weak external positions. Only governments, central banks, the IMF and a few other official holders can own SDRs. The allocation of SDRs provides each member with a free asset on which net interest is receivable and payable at the same rate. Consequently, if a member's SDR holdings rise above its allocation, it earns interest on the excess; conversely, if it holds fewer SDRs than allocated, it pays interest on the shortfall.

A proposal for a special one-time allocation of SDRs was approved by the IMF Board of Governors in September 1997 through the proposed Fourth Amendment of the Articles of Agreement. This allocation would double cumulative SDR allocations to SDR 42.9 billion. Its intent is to enable all members of the IMF, old and new, to participate in the increase in SDR reserves on an equitable basis. However, the Fourth Amendment has not yet come into force because the necessary consensus among IMF members has still to be achieved. The first requirement is thus to obtain the political support needed for approval. Subsequently, the developed countries (which hold $60 \%$ of quotas) could reach an agreement to place their allocations at the disposal of developing countries or multilateral funds that are in a position to carry out countercyclical lending appropriate to UDC needs.

Migrants' remittances, which World Bank figures put at some US $\$ 200$ billion in 2006, can be important to development, essentially for two reasons: (i) they are usually less procyclical than other private capital flows, making them a more stable and predictable financing source; (ii) remittance income tends to be spent on things like food, housing and basic services, thus providing an alternative social security network for UDCs. Since intermediation and transfer costs for remittances are substantial, any significant reduction in these would have a direct impact on the struggle for development. In view of this, the most important concrete objectives must be to lower sending costs and encourage physical and human capital investment and the use of banking services in the countries receiving remittances.

Where public-private alliances and global funds are concerned, the idea is to create stronger tax and economic incentives for private giving so that savers become involved with the system of solidarity financing, thereby providing support for the economic initiatives of partners and of natural or legal persons currently excluded from the banking system. Specifically, consideration is being given to the establishment of new mechanisms to encourage consumers, producers, philanthropists and bankers to contribute to international solidarity measures. One example of such mechanisms is the use of labelling that identifies donors and of payment methods that act as intermediaries in these operations (credit cards, for example).

Again, monetary and financial assets are traded in large, deep, liquid markets, many of them operating globally. International financial transactions (involving currency and securities) thus represent an attractive and highly dynamic tax base, whence the idea of taxing them.

Very low tax rates $(0.1 \%-0.2 \%$ in the more ambitious proposals, $0.01 \%-0.02 \%$ in the more moderate ones) ${ }^{8}$ could yield large revenues, provided they are applied in a reasonably coordinated way between the main financial centres. Furthermore, these taxes could help to correct externalities if they put a stop to transactions considered to be of zero or negative utility from the standpoint of market efficiency because they produce excessive price volatility. ${ }^{9}$

The effect of such a tax on investment decisions would probably be very slight compared to the effect of other measures or the impact of prudential regulation on the portfolio decisions of many financial organizations and intermediaries.

Taxes on financial transactions are often criticized from the standpoint of economic efficiency. It is complained that they would raise the costs and reduce the volume of transactions; that they would artificially alter the time horizon of investors at the expense of the short term; that they would reduce market liquidity and could thereby contribute indirectly to higher volatility; and that by their very nature they would give rise to cascade effects. It is also argued that their real impact cannot be known or foreseen and could be much greater than the theoretical burden of the tax; that their incidence would be arbitrary and would give rise to a risk of double taxation (particularly in the case of

\footnotetext{
${ }^{8}$ See Nissanke (2005) for a detailed analysis of proposals.

${ }^{9}$ Currency operations are seen as a special case; one possible objective of a tax on currency transactions would be to combat speculation and help stabilize exchange rates (Agüera Sirgo and García-Arias, 2000).
} 
transactions conducted through intermediaries or mutual funds); and that there would be a high risk of evasion. Nonetheless, the latest contributions to the debate (Nissanke, 2005) seem to have shown that there are technical mechanisms for establishing this tax and minimizing distortions from it. Clearly, the only obstacle remaining is a political one (Agüera Sirgo and García-Arias, 2000).

In the economic literature there have been a variety of proposals for taxing different activities that generate negative environmental externalities, e.g., so-called Pigovian taxes or, when they relate to protection of the environment, environmental taxes. Of all these proposals, the one that has received most attention is a tax on greenhouse gas emissions (most particularly $\mathrm{CO}_{2}$ ). This area of environmental taxation, which is beyond the scope of the present essay, may be the one that has generated the most publications in recent years. ${ }^{10}$

Some conclusions about these innovative financing instruments (Atkinson, 2005) should be set out here:

(i) the only two global taxes capable of generating enough revenue to meet the budgetary objective in question (an extra US\$ 50 billion or so annually) are a tax on international financial transactions and a tax on $\mathrm{CO}_{2}$ emissions. Both are technically feasible and would have a limited impact on efficiency and output.

(ii) given that technically and politically viable tax rates are at the lower end of the possible range, there is little chance of them yielding a double dividend. There will surely be no option but to choose between development financing instruments and instruments for dealing with negative externalities.

(iii) there are alternatives to global taxes: the extra resources needed could be raised just by implementing the International Finance Facility so that the required $0.7 \%$ of developed country GDP was spent on development cooperation.

(iv) advance estimates of the overall economic impact of the different policy instruments can only be approximate. Until these measures are implemented it will be impossible to ascertain their true impact and the total benefits and costs associated with them.

\footnotetext{
${ }^{10}$ See Sandmo (2005) for an excellent evaluation of the scope for generating development financing revenue from environmental taxes, and for a review of the literature on the subject.
}

Of the measures proposed, only three innovative initiatives have been tried out: a tax on airline tickets, the International Finance Facility for Immunisation (IFFIm) and advance market commitments (AMCs), designed to ensure there will be viable markets in future for vaccines or drugs currently being researched (Olivié and Steinberg, 2007).

In 2004, France, Chile and the United Kingdom proposed the creation of a national (not global) tax on airline tickets. At the Conference on Innovative Development Financing (Paris, February 2006), Brazil, Congo, Côte d'Ivoire, Cyprus, Gabon, Jordan, Luxembourg, Madagascar, Mauritius, Nicaragua and the United Kingdom supported the proposal and undertook to create the tax in the medium term, but without setting a specific deadline. Some 20 countries have now given their support to the initiative. The resources raised will be managed by UNITAID (an organization created in September 2006 as part of the World Health Organization) with a view to improving access to treatments for HIV-AIDS, malaria and tuberculosis in UDCs at below-market prices. Although the amount raised is not expected to be great (about US\$ 450 million a year), for the first time it has been shown that, with political will, it is possible to design and implement innovative taxes internationally.

The International Finance Facility for Immunisation, mentioned above, was created because there was not enough agreement to implement the IFF proposal (the basic stumbling blocks being governance, the use of funds and levels of leverage). This being so, the decision was taken to set up a kind of scaled-down IFF to finance a major vaccination programme.

Accordingly, all the new funding raised will be used to finance health programmes, particularly vaccinations. This is because there is a consensus that vaccination is linked to global public goods with high long-term yields and that failing to act (vaccinate) would undermine the growth and development potential of the UDCs. The project, which began operating in November 2006 and will generate US\$ 4 billion a year up to 2015, is being financed by Austria, Brazil, France, Germany, Italy, Spain, Sweden and the United Kingdom, and by the Bill and Melinda Gates Foundation. The resources raised by donations from these contributors will be managed and distributed by the Global Alliance for Vaccines and Immunization (GAVI), whose participants include the World Bank, the World Health Organization (WHO), UNICEF, the 
Bill and Melinda Gates Foundation and a number of donor and recipient country governments. The donations are earmarked for purchasing vaccinations and distributing them to 72 countries with annual per capita income of less than US\$ 1,000 , which will accelerate compliance with a number of Millennium Development Goals in lower-income countries by directly reducing child mortality and improving maternal health and indirectly reducing poverty and improving education.

Where AMCs are concerned, the goal is nothing less than to alter the structure of incentives for large transnational pharmaceutical companies so that these invest more in researching and producing drugs and vaccinations to cure or prevent diseases that are hugely prevalent in UDCs. The development of these drugs and vaccinations will take an enormous amount of investment, and the poverty of the countries affected by these evils means there is no guarantee of there being a market in which to sell them. In view of this, in February 2007 a number of countries (Canada, Italy, Norway, Russia and the United Kingdom) and the Bill and Melinda Gates Foundation donated US\$ 1.5 billion to promote research into a vaccine against pneumococcus disease. Although this measure has been criticized for not focusing on the search for a vaccine against malaria or HIV-AIDS, it may provide an empirical demonstration of the effectiveness of this type of system, with a view to its future implementation.

\section{V}

\section{External borrowing}

Borrowing from abroad has traditionally been a way for UDCs to supplement and enhance their domestic resources. Since all borrowing entails the payment of interest, however, these countries have been faced with growing debt service requirements which have impaired their growth prospects and required repeated restructuring or renegotiation of their borrowings (debt crises).

Given that debt servicing absorbs a large proportion of the official assistance and private capital flows received by UDCs, the Monterrey Consensus established that reducing or eliminating this cost was a very important additional source of development financing. Naturally, lower debt has to be accompanied by policies to mobilize the domestic resources of the recipient countries and to channel the resources freed from the burden of debt towards the attainment of long-term development goals. Again, total or partial debt forgiveness will only be effective if the borrowing carried out by these countries from that time on is kept at sustainable levels and is within their economic capacity to repay.

A historical analysis of the evolution of UDC borrowing reveals an especially dramatic situation: while most countries began to reduce their debt burden in the 1990s, the poorest and most heavily indebted countries saw that burden increase. Consequently, the Heavily Indebted Poor Countries
(HIPC) Initiative was implemented in 1996 with a view to reducing these countries' debt levels, renegotiating their Paris Club loans and allocating the resources thus liberated to development objectives.

Although the HIPC Initiative initially covered a period of three years, an extension was agreed in 1999 (the Enhanced HIPC Initiative). This ended in 2006 after benefiting 29 countries, having been extended from 2004. Nonetheless, the World Bank and IMF have drawn up a list of a further 11 countries that qualified as of 2006 for a process of debt forgiveness and restructuring similar to the HIPC Initiative.

In the 1996-2006 period, the effects in the 29 countries were moderately positive. Taken all together, the current value of their debts fell by two thirds (in 2005, debt service accounted for $2.5 \%$ of GDP in these 29 countries). Debt service as a proportion of exports declined on average from $16 \%$ in 1996 to $8 \%$ in 2005. Furthermore, some of the savings have indeed gone on development spending; for example, taking all 29 countries together, public spending on poverty reduction programmes rose from $6 \%$ of GDP in 1999 to $9 \%$ in 2005.

Despite the relative success of the HIPC Initiative, however, the large social spending commitments of these countries have exceeded the resources freed up by it, leading them to continue increasing their level of debt. 
In view of the persistence of external debt problems, new initiatives have been arising to palliate them. For example, a United Kingdom initiative, the Multilateral Debt Relief Initiative (MDRI), proposes a $100 \%$ reduction in debt servicing and a swap of debt for credits granted by the international financial institutions. Canada has made a similar proposal, but with bilateral financing. The United States has also made its contribution through the IMF, the African Development Fund, the International Development Association and many other bodies.

Nonetheless, all these initiatives are aimed at heavily indebted poor countries, whose total debt is in the region of US\$ 55 billion, while it is calculated that the total debts of UDCs are in the region of US\$ 2.3 trillion.

Countries that are heavily indebted but not very poor and middle-income debtor countries are not included in these initiatives and can only hope that something will come out of the so-called Evian Approach of the Paris Club, which advises its members to take a more lenient approach to debt problems.

\section{VI}

\section{Conclusions}

Financial internationalization and liberalization are among the most salient features of the economic globalization process and perfectly encapsulate the duality of that process, with its combination of opportunity and threat.

On the one hand, it theoretically makes available to every economy on the planet a vast quantity of resources poised to move instantly to wherever the most profitable investment opportunities are to be found. On the other, there seem to be all kinds of difficulties along the way, such as marketdominating oligopolistic agents driven by the herd instinct, resources concentrated in just a handful of financial centres, money-laundering, speculation, financing of illegal activities and recurrent financial and currency crises.

Where the issue of development is concerned, international finance displays the same dichotomy. Had it not grown so strongly over recent decades, it would be hard to account for the progress of economies such as China and India and those of
Accordingly, and while the initiatives undertaken so far have freed up resources for long-term development goals, it should not be forgotten that the Secretary General of the United Nations has defined debt sustainability as the level of debt that would allow a country to both achieve the Millennium Development Goals and reach 2015 without an increase in its debt ratios (United Nations, 2005). Obviously, for all HIPCs and for many low- and middle-income UDCs, this would simply mean $100 \%$ debt cancellation.

In any event, even if debt forgiveness were extended to all UDCs (which is not viable at present), the sustainability of new borrowing would depend greatly on these countries' growth prospects and their ability to participate in international trade. Debt sustainability ought to be part of a broader development strategy that takes a comprehensive and consistent approach to the issues of trade, finance and debt. Linking this issue with the idea of reforming the international financial architecture, there seems to be an urgent need for an international bankruptcy and defaults court.

South-East Asia, which have had access to constant flows of international capital to finance their economic progress. The other UDCs need private and public capital flows to help them escape from the trap of underdevelopment and poverty in which they find themselves.

At the same time, the international finance/ development connection brings exclusion for some and a threat for others: exclusion because many of the countries that need the most recourses are not among the destinations for private capital flows, a threat because in countries that do receive these flows the beneficial effects are undermined by problems of volatility, scarcity and geographical concentration, by the speculative character they often acquire, and most particularly by their reversibility.

In this context, ODA is required to play the role that habitually falls to every kind of public, institutional or at any rate not strictly private intervention: that of rectifying the imbalances and filling in the gaps left by the private sector (the 
market). Despite the relatively satisfactory progress of such assistance in recent years, however, there are still major problems to resolve. These concern, among other things, the inadequacy of the total amounts available, their structure and composition, their volatility and their high degree of geographical concentration and conditionality.

Of all these difficulties, the one most relevant to the subject being studied here is the fact that there is not enough ODA to achieve the most imperative development goals. As noted earlier, the development economics literature estimates that an extra US\$ 50 billion of assistance a year is needed to meet the Millennium Development Goals by the deadline (United Nations, 2001; Atkinson, 2005). Consequently, there are three alternatives: (i) increase traditional ODA, (ii) design and implement measures to secure additional financing or (iii) abandon the Millennium Development Goals.

If the third option is ruled out, it seems clear that a combination of the first two is the alternative with the best prospects of success. However, given the tendency for total ODA to decline in 2006 and 2007 (chiefly owing to structural problems with its composition) and the limited progress made in applying the innovative financing tools analysed here, the Millennium Development Goals are becoming reminiscent of the closing sequences of those old 1940s films where the hero walks away and is swallowed up by the fog.

To resist this image, we need to recall some of the recommendations put forward in this debate with a view to finally placing international finance at the service of development. In doing so, we shall concentrate exclusively on the three fundamental elements analysed in this essay: private capital flows, ODA and innovative financing instruments.

In the first place, there will need to be deep reforms to the international financial architecture through which international private financial flows move. In other words, financial liberalization ought to be considered, if at all, as the final step in a long process beginning, among other measures, with the implementation of an appropriate institutional and legal framework and the creation of deep, efficient and transparent national financial markets with widely available information and sound financial regulation.

In any event, if the decision is taken to go forward with this process, it ought to be supported by the whole of economic policy; it should be sequential, selective, gradual, economy-specific and capable of being slowed down or reversed if necessary, and it should be subject to the guidance and supervision of local and international economic authorities, who need to have appropriate oversight and regulation instruments available at all times (García-Arias, 2002a).

There is a need not only to improve the quantity, quality and transparency of information but also to adopt a more active position in the process, supervising and regulating financial and currency markets and the financial flows channelled through them. It is also necessary to work for the establishment of an international lender of last resort and an international bankruptcy and defaults court, take measures to combat money-laundering, make it harder for tax havens to be used to evade or avoid tax obligations and democratize international financial institutions. ${ }^{11}$

Second, it is important to fulfil the quantitative ODA commitments made by devoting $0.7 \%$ of donor countries' GDP to this purpose while ensuring that the resources provided are of high quality and, most importantly, are stable and constant. ODA should be used exclusively to finance anti-inequality measures, access to all fundamental economic and social rights and the provision of global public goods. ${ }^{12}$

Third, it seems indispensable to reform ODA instruments and rebalance the way they are managed so that partnership is prioritized over aid, with development being treated as a process of economic and social progress that involves the reduction of inequalities and access to fundamental human rights for all. It is also important to support national development strategies decided upon by sovereign nations, give priority to essential services, recognize the vital role played by civil society organizations, establish real partnerships between donor and recipient countries, support partnerships between civil societies and work to enhance the democratic process.

Lastly, it is vital to implement some of the innovative development financing methods proposed, specifically the suggested International Finance Facility (IFF) and supranational taxes. Where IFF is concerned, it must be understood that the funds raised by it should be treated as strictly

${ }^{11}$ See García-Arias (2002b) for further details.

12 See Kaul and others (1999, 2003) and García-Arias (2002b) for an in-depth analysis of global public goods. 
supplementary to those deriving from other ODA flows; should go to the poorest populations; should be used to guarantee the exercise of human rights and access to global public goods; should seek to keep conditionality to a minimum in general and to do away with such conditions as do not contribute directly to the attainment of development goals; and should promote renewed governance, with democratic, representative and transparent decisionmaking mechanisms in which the countries of the South and their representatives are partners.

Where fiscal measures are concerned, and tax policy in particular, supranational taxation has an indispensable role to play in complementing national taxation (given a context in which the role of public sectors has been affected by globalization) for at least three reasons (García-Arias, 2004): (i) the need to provide global public goods, which require stable and sustainable international public financing, (ii) the erosion of the position of public-sector economic authorities and especially their ability to raise the resources they require to meet the collective needs of their citizens, and (iii) the asymmetrical treatment given by traditional fiscal arrangements to owners of capital, which has undermined the traditional tax base of public sectors.

(Original: Spanish)

\section{Bibliography}

Agosin, M. and R. Mayer (2000): Foreign Investment in Developing Countries: Does It Crowd in Domestic Investment?, UNCTAD Discussion Paper, No. 146, UNCTAD/OSG/DP/146, Geneva.

Agüera Sirgo, J.M. and J. García-Arias (2000): Distorsiones del sistema financiero internacional: un impuesto sobre las transacciones financieras en divisas como alternativa, Revista de economía mundial, No. 2, Madrid, Complutense University of Madrid.

Asian Development Bank (2004): Asian Development Outlook, 2004, Manila.

Atkinson, A. (ed.) (2005): New Sources of Development Finance, New York, Oxford University Press.

Basu, A. and K. Srinivasan (2002): Foreign Direct Investment in Africa: Some Case Studies, IMF Working Paper, No. 02/61, Washington, D.C., International Monetary Fund.

Beynon, J. (2003): Poverty Efficient Aid Allocations: Collier/Dollar Revisited, Overseas Development Institute Working Paper, No. 2, London, Economics and Statistics Analysis Unit, Overseas Development Institute.

BIS (Bank for International Settlements) (2007): Triennial Central Bank Survey of Foreign Exchange and Derivatives Market Activity in April 2007. Preliminary Global Results, Basel. Available at: http://www.bis.org/publ/rpfx07.htm.

Bulir, A. and J. Hamann (2003): Aid Volatility: An Empirical Assessment, IMF Staff Papers, vol. 50, No. 1, Washington, D.C., International Monetary Fund.

Burnside, C. and D. Dollar (2000): Aid, Policies and Growth, Policy Research Working Paper, No. 1777, Washington, D.C., World Bank.

Caballero, R. (2003): On the International Financial Architecture: Insuring Emerging Markets, NBER Working Paper, No. 9570, Cambridge, Massachusetts, National Bureau of Economic Research.

Collier, P. and J. Dehn (2001): Aid, Shocks and Growth, Policy Research Working Paper, No. 2688, Washington, D.C., World Bank.
Collier, P. and D. Dollar (2001): Can the world cut poverty in half? How policy reform and effective aid can meet international development goals, World Development, vol. 29, No. 11, Amsterdam, Elsevier.

Collier, P. and A. Hoeffler (2002): Aid, Policy and Growth in Postconflict Countries, Policy Research Working Paper, No. 2902, Washington, D.C., World Bank.

Commission of the European Communities (2005): New Sources of Financing for Development: A Review of Options, Commission Staff Working Paper, SEC (2005) 467, Brussels.

Dalgaard, C.-J. and H. Hansen (2001): On aid, growth and good policies, Journal of Development Studies, vol. 37, No. 6, London, Taylor \& Francis.

Eatwell, J. (2002): The New International Financial Architecture: Promise or Threat, Cambridge, Cambridge Endowment for Research in Finance.

ECLAC (Economic Commission for Latin America and the Caribbean) (2005): Foreign Investment in Latin America and the Caribbean, 2004, LC/G.2269-P, Santiago, Chile.

Eichengreen, B. (1999): Toward a New International Financial Architecture: A Practical Post-Asia Agenda, Washington, D.C., The Institute for International Economics.

Eichengreen, B., R. Hausmann and U. Panizza (2003): Currency Mismatches, Debt Intolerance, and Original Sin: Why They Are Not the Same and Why It Matters, NBER Discussion Paper, No. 10036, Cambridge, Massachusetts, National Bureau of Economic Research.

García-Arias, J. (2002a): La crisis cambiaria y financiera de la ASEAN-4: liberalización financiera disfuncional y comportamiento de rebaño, Problemas del desarrollo: Revista latinoamericana de economía, vol. 33, No. 129, Mexico City, National Autonomous University of Mexico.

(2002b): Economía politica de la estabilidad cambiaria. Una perspectiva desde la teoría de los bienes públicos globales, Madrid, CES.

(2004): Mundialización y sector público: mitos y enseñanzas de la globalización financiera, Comercio exterior, 
vol. 54, No. 10, Mexico City, Banco Nacional de Comercio Exterior.

(2006): Information cascades and currency crises: a theoretical analysis, Investigación económica, No. 255, Mexico City, UNAM.

Griffith-Jones, S., R. Gottschalk and J. Cailloux (eds.) (2003): International Capital Flows in Calm and Turbulent Times: The Need for New International Architecture, Ann Arbor, University of Michigan Press.

Hansen, H. and F. Tarp (2000): Aid effectiveness disputed, Journal of International Development, vol. 12, No. 3, New York, Wiley.

Hanson, G. (2001): Should Countries Promote Foreign Direct Investment?, CID Discussion Paper Series, No. 9, New York, United Nations.

HM Treasury/Department for International Development (2003): International Finance Facility, London.

Kaul, I., I. Grunberg and M. Stern (1999): Global Public Goods: International Cooperation in the 21st Century, New York, Oxford University Press.

Kaul, I. and others (2003): Providing Global Public Goods: Managing Globalization, New York, Oxford University Press.

Kenen, P. (2001): The International Financial Architecture: What's New? What's Missing?, Washington, D.C., Institute for International Economics.

Morrissey, O. (2001): Does aid increase growth?, Progress in Development Studies, vol. 1, No. 1, Sage Publications.

Nissanke, M. (2005): Revenue potential of the Tobin Tax for development finance: a critical appraisal, in A. Atkinson (ed.), New Sources of Development Finance, New York, Oxford University Press.

Ocampo, J.A. (1999a): International financial reform: the broad agenda, CEPAL Review, No. 69, LC/G.2067-P, Santiago, Chile, December.

(1999b): Towards a New International Financial Architecture: Report of the Task Force of the Executive Committee on Economic and Social Affairs of the United Nations, LC/G. 2054, Santiago, Chile, March.
Ocampo, J.A., J. Kregel and S. Griffith-Jones (2007): International Finance and Development, London, Zed Books.

OECD (Organisation for Economic Co-operation and Development) (2008), Net Official Development Assistance in 2007: Preliminary Data for 2007. Available at: http: www.oecd.org/dac.

Olivié, I. and F. Steinberg (2007): Un balance de la ayuda al desarrollo 2006: ¿disminuye la ayuda?, ARI, No. 56, Madrid, Real Instituto Elcano.

Palazuelos, E. (1998): La globalización financiera: la internacionalización del capital financiero a finales del siglo $X X$, Madrid, Síntesis.

Pallage, S. and M.A. Robe (2001): Foreign aid and the business cycle, Review of International Economics, vol. 9, No. 4, Oxford, Blackwell Publishing.

Sandmo, A. (2005): Environmental taxation and revenue for development, in A. Atkinson (ed.), New Sources of Development Finance, New York, Oxford University Press.

UNCTAD (United Nations Conference on Trade and Development) (2003): World Investment Report, 2003. FDI Policies for Development: National and International Perspectives, Geneva.

United Nations (2001): Report of the High-Level Panel on Financing for Development, New York.

(2002): Report of the International Conference on Financing for Development (Monterrey, Mexico, 18-22 March), A/CONF. 198/11, New York.

(2005): In Larger Freedom: Towards Security, Development and Human Rights for All, New York.

Weller, C. (2001): The Supply of Credit by Multinational Banks in Developing and Transition Economies: Determinants and Effects, DESA Discussion Paper, No. 16, ST/ESA/2001/ DP.16, New York, United Nations.

World Bank (1998): Assessing Aid: What Works, What Doesn't and Why, New York, Oxford University Press.

(2004): Global Development Finance, 2004, Washington, D.C. 